\title{
LAPORAN SERI KASUS: STROKE PERDARAHAN PADA PASIEN DENGAN KEHAMILAN
}

\author{
Ditha Praritama Sebayang, Ismail Setyopranoto, Indrawati Setyaningsih
}

Departemen Neurologi, FK Universitas Gadjah Mada/RSUP Dr. Sardjito, Yogyakarta, Indonesia

Diterima 11 Agustus 2017

Disetujui 5 Mei 2018

Publikasi 21 Mei 2018

Korespondensi: drdithasebayang@gmail.com
Cara merujuk artikel ini: Sebayang (et al). 2018. Laporan Seri Kasus: Stroke Perdarahan pada Pasien dengan Kehamilan. Callosum Neurology Journal 1(2): 51-59. DOI: https://doi.org/10.29342/cnj.vli2.31

\begin{abstract}
ABSTRAK
Latar Belakang: Kehamilan dan pascapersalinan dikaitkan dengan peningkatan risiko stroke. Tidak banyak laporan kasus mengenai variasi manifestasi yang ada menjadi alasan pemilihan kasus ini.

Kasus 1: Ny.A berusia 36 tahun, G2P1A0 usia kehamilan 33 minggu dengan sindrom peningkatan tekanan intrakranial (PTIK), gangguan komunikasi, dan kelemahan anggota gerak kanan mendadak. Kesadaran pasien compos mentis dengan perdarahan intraserebral (PIS) di temporalis sinistra sebanyak $21 \mathrm{~mL}$.
\end{abstract}

Kasus 2: Ny.S berusia 38 tahun, G3P2AO usia kehamilan 35 minggu dengan sindrom PTIK, kelemahan anggota gerak kanan, pelo, dan perot yang mendadak. Kesadaran pasien sopor (E3V2M5) dengan PIS di temporoparietalis sinistra sebanyak $42,5 \mathrm{~mL}$.

Diskusi: Kedua pasien dirawat di Unit Stroke Rumah Sakit Umum Pusat Dr. Sardjito mengalami PIS dengan kecurigaan lesi vaskular sekunder (AVM atau aneurisma) sebagai etiologinya. Simpulan: Kondisi PIS dalam kehamilan dan pascapersalinan menyebabkan morbiditas dan mortalitas.

Kata Kunci: Stroke, perdarahan intraserebral, kehamilan

\begin{abstract}
Background: Pregnancy and the postpartum period are associated with an increased risk of stroke. Lacking of case report underlied the choice of these cases.

Case 1: Mrs. A, 36 years old, G2P1A0, 33 weeks pregnancy with increased intracranial pressure syndrome (IICP), communication disturbance, and right hemiparesis. The patient is compos mentis with intracerebral hemorrhage (ICH) $21 \mathrm{~mL}$ volume in left temporal.

Case 2: Mrs. S, 38 years old, G3P2A0, 35 weeks pregnancy with IICP, right hemiparesis, and slurred speech. Patient is sopor with intracerebral hemorrhage (ICH) $21 \mathrm{~mL}$ volume in left temporoparietal.
\end{abstract}

Discussion: Both patients had ICH with suspected etiology was secondary vascular lesion (AVM or aneurysm). Management for both patients with ICH guideline and adjusted with the maternal and fetal condition

Conclusion: Intracerebral hemorrhage during pregnancy and postpartum is a significant cause of morbidity and mortality. Management of $\mathrm{ICH}$ during pregnancy may require interdisciplinary care from neurosurgery, neurology, and obstetrics. Keywords: Stroke, intracerebral hemorrhage, pregnancy 


\section{Latar Belakang}

Kehamilan dan periode pascapersalinan berhubungan dengan meningkatnya risiko stroke iskemia maupun perdarahan. Stroke jarang terjadi pada usia muda namun apabila terjadi pada perempuan yang sedang hamil maka kondisi tersebut akan sangat membahayakan ibu dan janin. Insiden stroke berkisar 9-26 kasus dalam 100.000 kehamilan dan persalinan. Penyebab stroke pada kehamilan dan pascapersalinan yaitu preeklampsia, eklampsia, emboli cairan amnion, angiopati pascapersalinan, dan kardiomiopati pascapersalinan. ${ }^{1}$

Stroke perdarahan mencakup 38\% dari semua kasus stroke terkait kehamilan. Perdarahan subarakhnoid oleh karena aneurisma dan ruptur malformasi arteriovenosa merupakan penyebab yang paling dominan. Penyebab lain perdarahan intraserebral (PIS) pada kehamilan yaitu preeklampsia dan eklampsia, koagulopati, trauma, dan cerebral venous thrombosis. Kondisi disseminated intravascular coagulation (DIC) yang muncul segera setelah pascapersalinan pernah dilaporkan sebagai penyebab PIS. Perdarahan intraserebral menyebabkan $7,1 \%$ dari keseluruhan angka kematian maternal. Risiko PIS meningkat saat mendekati persalinan dan masa nifas. Risiko relatif PIS terjadi pada 2,5\% selama kehamilan dan 28,3\% pada masa nifas. ${ }^{2}$

Stroke dapat membahayakan bagi ibu dan janin. Potensi membahayakan dapat berasal dari perjalanan alamiah kasus maupun terkait penatalaksanaan pasien. Penegakan diagnosis stroke pada kehamilan serupa dengan kondisi tanpa kehamilan. Kehamilan bukan merupakan kontraindikasi pemeriksaan $X$-ray jika memang dianggap perlu. Prinsip penatalaksanaan kasus PIS juga serupa pada kondisi kehamilan maupun tanpa kehamilan, namun memerlukan pengambilan keputusan yang lebih hati-hati mempertimbangkan kondisi obstetrik maternal dan fetal. ${ }^{3}$ Laporan kasus ini membahas mengenai identifikasi faktor risiko, potensi etiologi, penanganan, serta strategi pencegahan kondisi stroke pada kehamilan.

\section{Ilustrasi Kasus}

Kasus 1

Ny. A berusia 36 tahun tanpa memiliki riwayat penyakit yang signifikan sebelumnya. Pasien menggunakan metode keluarga berencana (KB) hormonal sebelum kehamilan. Saat ini merupakan kehamilan kedua dengan umur kehamilan 33 minggu. Pasien rutin memeriksakan diri selama kehamilan. Anak pertama pasien telah berusia 12 tahun.

Pada hari masuk rumah sakit, pasien mendadak mengalami nyeri kepala berat disertai dengan muntah menyemprot beberapa kali diikuti, dengan kelemahan anggota gerak kanan, pelo, perot serta kesulitan komunikasi.

Pemeriksaan fisik menunjukkan status kesadaran kompos mentis dengan afasia global dan hemiparesis dekstra. Tekanan darah saat masuk 150/90mmHg. Hasil pemeriksaan urin menunjukkan proteinuria +1 . Pemeriksaan obstetrik menunjukkan tinggi fundus uteri (TFU) sesuai dengan usia kehamilan, denyut jantung janin (DJJ) terdengar dan regular, tanpa disertai kontraksi uterus maupun perdarahan.

Penilaian klinis tidak menunjukkan terjadinya kondisi eklampsia. Selanjutnya dilakukan pemeriksaan penunjang dengan Computed Tomography (CT)-scan kepala yang menunjukkan adanya PIS di lobus temporalis kiri bervolume 21 $\mathrm{mL}$ tanpa adanya perdarahan ventrikel maupun herniasi (Gambar 1).

\section{Kasus 2}

Ny. S berusia 38 tahun tanpa memiliki riwayat penyakit yang signifikan sebelumnya. Pasien menggunakan metode KB hormonal sebelum kehamilan. Saat ini merupakan kehamilan ketiga dengan umur kehamilan 35 minggu. Pasien rutin memeriksakan diri selama kehamilan. Anak pertama pasien telah berusia 7 tahun, sedangkan anak kedua berusia 2 tahun.

Pasien mengalami penurunan kesadaran diawali dengan keluhan kelemahan anggota gerak kanan sejak 2 hari sebelumnya disertai dengan keluhan nyeri kepala berat, pelo, dan perot.

Pemeriksaan fisik menunjukkan status kesadaran sopor (E3V2M5) dengan lateralisasi pada sisi tubuh kanan. Tekanan darah saat masuk 128/70mmHg. Hasil pemeriksaan urin menunjukkan proteinuria +1 . Pemeriksaan obstetrik menunjukkan TFU sesuai dengan usia kehamilan, DJJ terdengar dan 
regular, tanpa disertai kontraksi uterus maupun perdarahan.

Penilaian klinis tidak menunjukkan terjadinya kondisi eklampsia. Selanjutnya dilakukan pemeriksaan penunjang dengan CT-scan kepala yang menunjukkan adanya PIS di lobus temporoparietal kiri dengan herniasi subfalcine ke laterodekstra sejauh $0,5 \mathrm{~cm}$ dan edema serebri tanpa disertai perdarahan ventrikel (Gambar 2).

Pasien dirawat di Unit Stroke Rumah Sakit Umum Pusat Dr Sardjito.

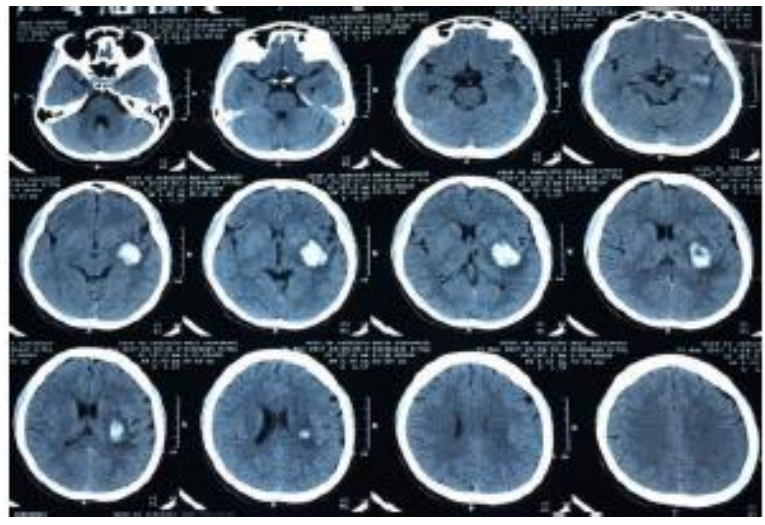

Gambar 1. CT-scan kepala Ny. A

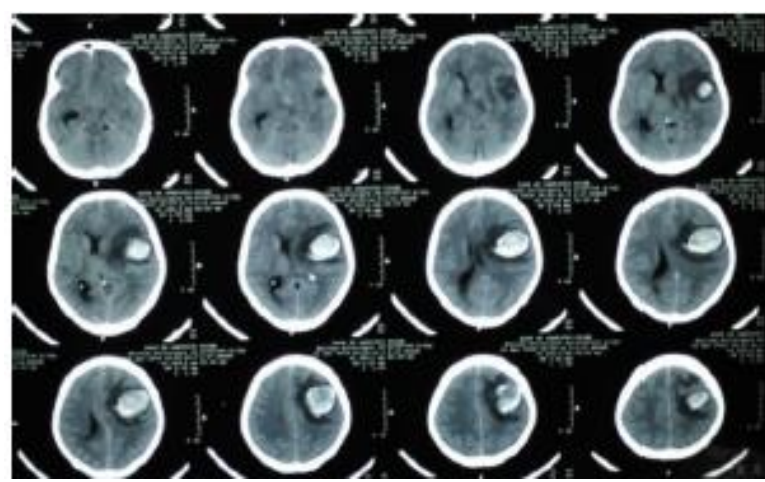

Gambar 2. CT-scan kepala Ny. S

\section{Diskusi}

Perubahan saat kehamilan dapat menjadi faktor risiko stroke. Ada empat faktor utama patofisiologi stroke pada kehamilan. ${ }^{4}$

1. Faktor hemodinamik. Selama kehamilan, total volume cairan tubuh meningkat sebanyak $50 \%$, dimulai dari 10 minggu pascagestasi dan akan turun setelah 2 minggu pascapersalinan. Peningkatan terjadi pada cardiac output, stroke volume, dan denyut jantung yang disebabkan oleh meningkatnya kebutuhan janin dan plasenta serta status hipervolemik kronis. Tekanan darah dapat menurun disebabkan penurunan resistensi pembuluh darah sistemik. Peningkatan venous compliance selama kehamilan menyebabkan penurunan aliran darah tubuh dan meningkatkan stasis vena. Beberapa faktor tersebut dapat mencetuskan status hipervolemia, peningkatan kebutuhan sirkulasi, penurunan tekanan darah, dan peningkatan stasis vena yang kemudian dapat mengubah pola hemodinamik normal.

2. Perubahan koagulabilitas. Perubahan fisiologis selama kehamilan menimbulkan pergeseran ke arah hypercoagulable. Terjadi peningkatan banyak faktor pembekuan darah, termasuk faktor prokoagulan I, VII, VIII, IX, X, XII, dan XIII. Hal ini akibat perpindahan plasenta dan pelepasan faktor protrombotik yang selanjutnya berperan untuk mencegah perdarahan. Perubahan faktor protrombotik ini terutama terjadi di trimester ketiga yang akan kembali turun pada tiga minggu pascapersalinan.

3. Perubahan jaringan ikat. Studi pada hewan menunjukkan terjadinya perubahan arsitektur arteri serebral selama kehamilan. Terjadinya penurunan kolagen, elastisitas, dan distensibilitas arteri serebral. Belum jelas diketahui apakah hal yang sama terjadi pada manusia. Hipotesis ketidakmampuan mengimbanginya arteri sererbal terhadap kondisi hipervolemia dan peningkatan kebutuhan jantung dapat menyebabkan peningkatan risiko stroke perdarahan.

4. Vaskulopati yang terjadi pada kehamilan. Manifestasi vaskulopati bermacam-macam. Preeklampsia dan eklampsia berhubungan dengan kondisi hipertensi dan proteinuria saat kehamilan. Preeklamsia dan eklampsia terbukti sebagai faktor risiko independen dan berhubungan dengan peningkatan stroke empat kali lipat selama kehamilan. Hipertensi gestasional digambarkan sebagai tekanan darah sistolik $\geq 140 \mathrm{mmHg}$ atau tekanan darah diastolik $\geq 90 \mathrm{mmHg}$ tanpa proteinuria. Sekitar 8- 12\% wanita hamil mengalami hipertensi dan berisiko tinggi mengalami hipertensi kronis dan stroke di kemudian hari. Angiopati pascapersalinan merupakan kondisi unik yang berhubungan dengan kehamilan melalui 
mekanisme reversible cerebral vasocontriction syndromes (RCVS). Angiopati pascapersalinan tidak hanya terbatas pada pasien dengan riwayat preeklamsia atau eklampsia, namun dapat terjadi pada kehamilan tanpa komplikasi serta persalinan tanpa riwayat hipertensi. Gejalanya meliputi nyeri kepala, muntah, perubahan status mental, dan/ atau defisit neurologis fokal. Awitan gejala klasik terjadi dalam lima hari setelah melahirkan. Diagnosis ditegakan dengan

5. visual, dan ensefalopati global. Vaskulopati ini dapat dipicu oleh keadaan darurat hipertensi, paparan imunosupresif, preeklampsia, atau eklampsia. Diagnosis berdasarkan gejala klinis dan temuan edema subkortikal vasogenik pada magnetic resonance imaging (MRI). Pemulihan klinis terjadi dalam beberapa hari dengan resolusi kelainan MRI dalam rentang hari sampai minggu.

Stroke selama kehamilan jarang terjadi, namun dapat meningkat akibat kejadian hipertensi pada perempuan muda sebelum dan selama usia masa subur. Identifikasi faktor risiko stroke selama kehamilan sangat penting untuk mencegah kondisi yang cukup jarang namun dapat sangat membahayakan bagi ibu dan janin. Perkiraan kejadian stroke terkait kehamilan adalah 10,2 per 100.000 kelahiran. Insiden stroke perdarahan saat kehamilan dan masa nifas pada penelitian sebelumnya ditemukan sebanyak 111 kasus $(73,5 \%)$, stroke iskemia sebanyak 37 kasus $(24,5 \%)$, dan tipe campuran pada 3 kasus $(2,0 \%)$. Kejadian stroke perdarahan secara keseluruhan pada kehamilan adalah 56 kasus (50,5\%), 16 kasus $(14,4 \%)$ saat melahirkan, dan 39 kasus $(35,1 \%)$ selama masa puerperium. Penyebab utama perdarahan adalah aneurisma (19,8\%), AVM $(17,1 \%)$, hipertensi yang diinduksi kehamilan $(11,7 \%)$, dan sindrom HELLP (hemolisis, peningkatan enzim hati, dan jumlah trombosit yang rendah) $(8,1 \%)$, angioma kavernosus $(7,2 \%)$, RCVS $(4,5 \%)$, penyakit Moyamoya $(1,8 \%)$, dan kejadian serebrovaskular lainnya $(7,2 \%)$. Penyakit serebrovaskular yang sudah ada sebelumnya bertanggung jawab atas terjadinya perdarahan pada 59 kasus (53,1\%). Kejadian ruptur aneurisma angiografi yang menunjukkan penyempitan segmen multifokal pada arteri serebral berukuran besar dan menengah, temuan ini sering membingungkan dengan vaskulitis. Posterior reversible encephalopathy syndrome (PRES), yang juga disebut sebagai leukoencephalopathy posterior reversible syndrome (RPLS), dikaitkan dengan edema subkortikal vasogenik reversibel, pada lobus parietal dan oksipital. Gejala klinis PRES antara lain nyeri kepala, bangkitan, gejala meningkat dengan kehamilan dan memiliki kecenderungan yang lebih besar terjadi selama periode trimester ketiga dan pascapersalinan $(\geq 24$ jam), sedangkan kejadian ruptur AVM memuncak pada trimester kedua dan menurun setelah melahirkan. Di antara delapan kasus kehamilan dengan angioma kavernosus, tiga kasus terjadi pada trimester pertama, empat kasus terjadi pada trimester ketiga, dan satu kasus terjadi pada periode pascapersalinan ( $\geq 24$ jam). Berbeda dengan tingginya angka stroke hemoragik karena faktor risiko yang sudah ada sebelumnya, kejadian stroke hemoragik karena komplikasi obstetrik sangat terfokus pada masa persalinan dan pascapersalinan awal ( $<24$ jam). Pada kejadian stroke iskemia, 28 $(75,7 \%)$ adalah infark arteri dan $9(24,3 \%)$ adalah infark vena. Penyebab infark arteri yang paling sering adalah RCVS. Stroke hemoragik menunjukkan prognosis yang jauh lebih buruk daripada stroke iskemia. Pasien dengan aneurisma, AVM, dan sindrom HELLP menempati kurang lebih $60 \%$ dari stroke perdarahan yang terjadi saat kehamilan. 5

Kedua kasus di atas menunjukkan temuan klinis berupa riwayat nyeri kepala intensitas sedang-berat, riwayat muntah proyektil, afasia global, hemiparesis kanan, paresis nervus kranialis VII kanan tipe upper motor neuron (UMN), hipertensi stadium I, dan hasil CT-scan kepala menunjukkan adanya perdarahan. Perdarahan intraserebral pada kedua kasus tersebut menyebabkan defisit neurologis berupa hemiparesis kanan, afasia global, dan sindrom PTIK. CT-scan kepala menunjukkan adanya PIS, sehingga diperlukan analisis lanjutan meliputi lokasi perdarahan, perkiraan etiologi, manifestasi klinis berdasarkan lokasi yang terlibat, drainase cairan serebrospinal (ventrikel dan spasme 
subarakhnoid), serta efek massa akibat perdarahan tersebut. Usia kedua pasien masih relatif muda, hal ini sering berhubungan dengan anomali vaskular kongenital seperti AVM atau aneurisma serebral. Diperlukan pelacakan lebih lanjut guna mengetahui etiologi PIS pasien tersebut.

Perdarahan intraserebral terjadi pada $10-15 \%$ kasus dengan $50 \%$ diantaranya mengakibatkan hal yang fatal. Sekitar 80\% merupakan kasus PIS primer dan $20 \%$ merupakan kasus PIS sekunder. Hipertensi merupakan faktor risiko pada $50 \%$ kasus PIS primer dan sekitar 30\% disebabkan oleh amiloid angiopati serebral. Perdarahan intraserebral sekunder disebabkan oleh transformasi perdarahan pada stroke infark, malformasi pembuluh darah (aneurisma, AVM, angioma venosus, dural arteriovenosa fistule, dan cavernoma), neoplasma, trauma, vaskulitis, Moyamoya, dan trombosis sinus vena. ${ }^{6}$

Komplikasi lanjutan yang kompleks dapat terjadi pada PIS. Proses desak ruang dapat menyebabkan penekanan parenkim otak hingga herniasi serebri. Kombinasi efek massa yang berlanjut iskemia parenkim sekitar serta toksisitas produk darah menyebabkan terjadinya kematian neuron. Kerusakan sawar darah otak menyebabkan kebocoran cairan dan protein yang berkembang menjadi edema serebri. Terdapat tiga fase edema pada perdarahan intraserebral, yaitu fase awal pada jam pertama terjadi peningkatan tekanan hidrostatik oleh efek hematom, fase kedua pada hari berikutnya terjadi kasakade koagulasi dan produksi thrombin, dan fase ketiga terjadi lisisnya eritrosit dan toksisitas hemoglobin yang menyebabkan neurotoksik dan mekanisme apoptosis. ${ }^{7}$ Perdarahan dapat meluas ke dalam ruang ventrikel melalui vena periependimal sehingga menyebabkan hidrosefalus dan meningkatkan angka mortalitas. Perdarahan intraventrikular primer jarang terjadi. Hipertensi dan vaskulitis merupakan penyebab utama perdarahan intraventrikular primer. Setengah kasus perdarahan intraventrikular primer dapat diidentifikasi dengan angiografi. ${ }^{8}$

Identifikasi pasien dengan PIS sekunder penting untuk penatalaksanaan risiko perdarahan berulang yang berbeda dengan PIS primer. Pada beberapa kasus, PIS disebabkan oleh lesi vaskular seperti AVM maupun aneurisma intrakranial yang mengalami ruptur intraparenkim, serta dural venous sinus thrombosis (DVST). Telah dikembangkan penilaian untuk memprediksi etiologi PIS yang berasal dari lesi vaskular berdasarkan identifikasi klinis dan CT-scan tanpa kontras. ${ }^{9}$ Berdasarkan Tabel 1, total nilai 0-2 menunjukkan rendahnya PIS yang disebabkan oleh lesi vaskular, sedangkan total nilai $\geq 3$ menunjukkan tingginya kemungkinan PIS yang disebabkan oleh lesi vaskular. ${ }^{10}$

Tabel 1. Kalkulasi skor Secondary Intracerebral Hemorrhage (SICH)*

\begin{tabular}{ll}
\hline Parameter & Poin \\
\hline Kategori Computed Tomography (CT) & \\
non-kontras & \\
$\quad$ Probabilitas tinggi & 2 \\
Tidak dapat ditentukan & 1 \\
$\quad$ Probabilitas rendah & 0 \\
\hline Kelompok usia & \\
$\quad$ 18-45 tahun & 2 \\
$46-70$ tahun & 1 \\
$\quad \geq 71$ tahun & 0 \\
\hline Jenis kelamin & \\
$\quad$ Perempuan & 1 \\
$\quad$ Laki-laki & 0 \\
\hline Tidak terdapat hipertensi dan gangguan & \\
koagulasi & \\
$\quad$ Ya & 1 \\
$\quad$ Tidak & 0 \\
\hline
\end{tabular}

\section{Aneurisma serebral}

Aneurisma serebral adalah dilatasi fokus patologis serebrovaskular yang rentan pecah. Aneurisma serebral terjadi pada $1-5 \%$ populasi dewasa. Kelainan vaskular diklasifikasikan berdasarkan patogenesis. Sakular, berry, atau aneurisma kongenital merupakan $90 \%$ dari semua aneurisma otak dan terletak pada titik-titik cabang utama dari arteri besar. Dolichoectatic, fusiform, atau aneurisma arteriosklerotik yang memanjang dari arteri proksimal terdapat $7 \%$ dari seluruh aneurisma otak. Aneurisma infeksi atau mikotik terletak perifer dan terdiri $0,5 \%$ dari semua aneurisma otak. Lesi perifer lainnya termasuk aneurisma neoplastik, fragmen tumor embolized, dan aneurisma traumatis. Luka trauma juga dapat mengakibatkan aneurisma pada pembuluh proksimal. Mikroaneurisma pembuluh darah berdiameter kecil umumnya diakibatkan oleh kondisi hipertensi. ${ }^{11}$ 
Aneurisma sakular terletak di sirkulasi anterior pada $85-95 \%$ kasus, sedangkan aneurisma dolichoectatic lebih banyak terletak pada sistem vertebrobasilar. Lokasi aneurisma sakular bervariasi di segmen arteri, hal ini karena perbedaan populasi penelitian yang dilaporkan. ${ }^{12}$

\section{Malformasi Arteriovenousa}

Malformasi arteriovenosa serebri merupakan koneksi abnormal arteri dan vena yang melebar dalam parenkim otak serta tidak adanya organisasi pembuluh darah normal di subarteriolar. Arteri kecil yang terlibat dalam malformasi arteri kekurangan lapisan otot halus. Koneksi arteri abnormal dan vena pada malformasi (disebut sebagai nidus arterivena) dihubungkan oleh satu atau beberapa fistula. Hubungan langsung arterivena menghasilkan tekanan vaskular yang tinggi, terutama pada pembuluh darah dengan penebalan fibromuskular dan lamina elastis yang inkompeten sehingga pembuluh darah ini berisiko pecah. Perdarahan intraserebral pada AVM terjadi pada 42-72\% kasus. Perdarahan pertama paling sering terjadi pada pasien usia 20-40 tahun. Kejadian PIS akibat AVM sekitar $2 \%$ dari semua kasus stroke. ${ }^{13}$

3. terapi obat anti epilepsi. Tipe bangkitan yang sering terjadi adalah bangkitan umum. Pasien yang mengalami bangkitan tidak meningkatkan risiko ruptur AVM.

4. Nyeri kepala. Keluhan ini muncul pada 5$14 \%$ pasien dengan AVM. Nyeri kepala yang dialami dapat unilateral atau bilateral, menyerupai migrain dengan atau tanpa aura.

5. Defisit neurologis fokal. Muncul pada 1- $40 \%$ pasien dan $5-15 \%$ di antaranya tidak berhubungan dengan perdarahan. ${ }^{13}$

Ruptur AVM sering terjadi pada akhir usia kehamilan. Penelitian sebelumnya menunjukan bahwa risiko ruptur AVM tidak meningkat selama kehamilan dan masa nifas. Namun demikian didapatkan insiden ruptur AVM lebih sering pada masa usia akhir gestasi. Oleh karena itu harus menjadi perhatian agar menjaga hemodinamik selalu stabil selama trimester kedua dan ketiga. ${ }^{14}$ Angiografi serebral (digital substraction angiography/ DSA) adalah baku emas penegakan diagnosis AVM yang dapat menunjukkan arteri
Terjadinya perubahan fisiologis kardiovaskular pada ibu hamil dapat mempengaruhi struktural AVM dan berisiko menyebabkan perdarahan. Bila tidak dilakukan tata laksana yang adekuat dapat mengakibatkan ancaman yang serius pada ibu dan janinnya. ${ }^{14}$ Malformasi arteriovenosa sering tidak menunjukkan gejala sampai terjadi bangkitan atau perdarahan. Malformasi arteriovenosa mempunyai berbagai gejala dan tanda klinis, yaitu:

1. Perdarahan intraserebral. Angka kejadian perdarahan karena ruptur AVM yang tidak ditangani sebesar $2-4 \%$ pada $38-71 \%$ pasien AVM dengan PIS. Kejadian perdarahan paling sering terjadi pada usia 20-40 tahun. Tidak didapatkan data yang menunjukkan bahwa perdarahan saat ini menjadi prediktor perdarahan berikutnya. Risiko perdarahan pada AVM meliputi drainase vena dalam, berhubungan dengan aneurisma, AVM letak dalam, dan pada daerah infratentorial. Risiko perdarahan pada AVM letak dalam adalah $34,4 \%$.

2. Bangkitan. Insiden bangkitan pada AVM berkisar $18-40 \%$ dan berespons baik dengan

penyuplai, lokasi nidus, drainase vena, morfologi, aneurisma dan lokasinya, varises vena, dan stenosis arteri atau vena. Hal tersebut sangat penting karena berhubungan dengan rencana terapi selanjutnya. Modalitas pemeriksaan penunjang lainnya yang dapat membantu antara lain CT angiografi, MRI, dan magnetic resonance angiography (MRA). Masing-masing pemeriksaan penunjang tersebut mempunyai kemampuan spesifik, CT angiografi dapat menampilkan detail vaskular dari AVM yang lebih baik, MRI dan MRA menampilkan visualisasi yang lebih baik dari struktur yang mengelilingi nidus, MRI juga dapat mendeteksi trombosis vena karena terdapat gambaran hiperintens. ${ }^{15}$ Meskipun risiko paparan radiasi pada janin merupakan suatu perhatian penting saat memilih suatu pemeriksaan. Beberapa penelitian sebelumnya menunjukan bahwa dosis paparan radiasi DSA pada janin sangat kecil. Pelindung timbal pada perut dan panggul efektif melindungi pasien dengan kehamilan yang memerlukan pemeriksaan CT scan kepala. ${ }^{16}$

Manajemen terapi dan pembedahan guna menangani kondisi ruptur AVM selama kehamilan 
dan masa nifas cukup sulit dan kontroversial. ${ }^{13}$ Reseksi segera pada AVM tidak menunjukan hasil yang baik selama kehamilan dibandingkan dengan perawatan konservatif. ${ }^{17}$ Terapi konservatif pada pasien dengan AVM Spetzler Martin tingkat V dan VI menunjukkan angka morbiditas dan mortalitas yang lebih rendah dibandingkan terapi pembedahan, sebaliknya operasi evakuasi hematoma dan reseksi segera AVM sebaiknya dilakukan pada pasien AVM Spetzler Martin tingkat I-IV dengan tanda herniasi serebri. Prosedur pembedahan pada pasien dengan usia kehamilan akhir sebaiknya dilakukan setelah operasi sectio cesarean. Diperlukan kolaborasi yang lebih jauh dari tim multidisiplin antara lain neurologi, bedah saraf, obstetri ginekologi, anestesi, pediatri, dan perawatan intensif dalam managemen pasien. ${ }^{14}$

Konfirmasi diagnosis stroke pada kedua kasus di atas menggunakan pemeriksaan CT-scan kepala. Gambaran hiperdens di lobus temporal sinistra yang menunjukan gambaran PIS. Kedua pasien belum menjalani prosedur DSA. Nyeri kepala pada stroke perdarahan berhubungan dengan PTIK akibat traksi struktur peka nyeri intrakranial. Muntah terjadi akibat adanya distorsi pada ventrikel empat dimana disekitarnya terdapat nukleus vastibular serta pusat muntah.

Prinsip tata laksana stroke pada fase akut meliputi: ${ }^{18}$

1. Membantu proses restorasi dan plastisitas otak. Target terapi adalah mempertahankan wilayah oligemia iskemia penumbra dengan cara membatasi durasi iskemia dan derajat keparahan cedera iskemia (proteksi neuronal). Pencegah juga pada kondisi hipertermi, hipotermi, hipertensi, hiperglikemia, hipoglikemia, PTIK, infeksi, gangguan elektrolit, dan bangkitan.

2. Mengidentifikasi dan mengendalikan faktor risiko. Modifikasi terhadap faktor risiko yang dapat dimodifikasi dan mengembalikannya ke level normal. Sebagai contoh, pasien dengan hipertensi, target pengendalian tekanan darah setelah lewat fase akut stroke hingga di bawah 140/90mmHg, sedangkan bila pasien sebelumnya menderita hipertensi dan diabetes melitus maka dipertahankan di bawah 135/85mmHg.
3. Mencegah komplikasi. Beragam komplikasi yang kerap terjadi pada pasien tirah baring adalah pneumonia, dekubitus, dan infeksi saluran kemih. Pasien mutlak harus menjalani fisioterapi. Pada fase akut pasien belum dapat berpartisipasi penuh pada program terapi aktif, untuk itu dilakukan latihan range of motion (ROM) setiap hari dan positioning yang tepat untuk mencegah pemendekan dan kontraktur sendi. Terapi aktif dapat dilakukan perlahanlahan (isometrik, isotonik, isokinetik). Pasien tetap dimonitor untuk kemungkinan tidak stabilnya hemodinamik dan aritmia jantung, intensitas latihan juga harus dimonitor, karena otot yang terlalu keras berlatih justru akan membuat kelemahan semakin progresif.

Rekomendasi dikeluarkan oleh American Heart Association/ American Stroke Association (2015) terkait prosedur operasi pada kasus PIS. Perdarahan serebelum dengan pemberatan defisit neurologis, kompresi batang otak, dan/ atau hidrosefalus akibat obstruksi ventrikel. Sesegera mungkin harus menjalani prosedur evakuasi perdarahan. Tidak direkomendasikan drainase ventrikel sebagai terapi awal sebelum evakuasi perdarahan. Manfaat tindakan operasi belum dapat dipastikan pada kasus perdarahan supratentorial, namun evakuasi perdarahan supratentorial pada pasien yang mengalami deteriorisasi merupakan tindakan life saving. Evakuasi perdarahan saat terjadi penurunan kondisi pasien lebih bermanfaat dibandingkan dilakukan saat awal stroke. Prosedur kraniektomi dekompresi dengan atau tanpa evakuasi perdarahan menurunkan mortalitas pasien kesadaran koma dengan perdarahan supratentorial, perdarahan yang luas dengan pergeseran midline, dan PTIK yang refrakter terhadap pengobatan. Efektivitas prosedur evakuasi clot secara invasif minimal dengan stereotaktik atau aspirasi endoskopik dengan atau tanpa penggunaan trombolitik tidak dapat ditentukan.

\section{Manajemen peningkatan tekanan intrakranial}

Secara umum, manajemen PTIK berupa monitoring hemodinamik yang invasif serta resusitasi serebrovaskular yang cepat dapat menyelamatkan jiwa. Target terapi adalah tekanan intrakranial 
kurang dari $20 \mathrm{mmHg}$ dengan cerebral perfusion pressure (CPP) $>70 \mathrm{mmHg}$. Penatalaksanaan penderita dengan PTIK meliputi:

1. Meninggikan posisi kepala $20-30^{\circ}$.

2. Menghindari penekanan vena jugular.

3. Menghindari pemberian cairan glukosa atau cairan hipotonik.

4. Menghindari hipertermia.

5. Menjaga normovolemia.

6. Pemberian osmoterapi dengan:

- Manitolisasi dengan dosis 0,25-0,50 $\mathrm{gr} / \mathrm{KgBB}$ pemberian selama 20 menit, diulangi setiap 4-6 jam dengan target osmolaritas di bawah $310 \mathrm{mOsm} / \mathrm{L}$.

- Bila perlu berikan furosemid dengan dosis $1 \mathrm{mg} / \mathrm{KgBB}$ intravena.

7. Intubasi untuk menjaga normoventilasi (pCO2: $\quad 35-40 \quad \mathrm{mmHg}$ ). Hiperventilasi mungkin diperlukan bila akan dilakukan tindakan operatif.

\section{Prognosis}

Faktor yang paling berpengaruh terhadap prognosis stroke perdarahan jangka pendek adalah perluasan perdarahan ke ventrikel, tingkat kesadaran saat awal serangan, dan volume perdarahan. ${ }^{17}$ Stratifikasi risiko sebagai penentuan prognosis PIS sesuai dengan tabel 2. Kedua pasien pada laporan kasus ini memiliki skor PIS bernilai 0. Hasil ini berkorelasi dengan mortalitas dalam 30 hari sebesar $0 \% .{ }^{19}$

Stroke merupakan penyebab kecacatan kronis. Gejala klinis kelemahan anggota gerak sesisi serta bicara pelo akan mengganggu aktivitas sehari-hari. Tingkat kepuasan terhadap luaran stroke sangat tergantung pada jenis pekerjaan pasien yang dilakukan sehari-hari. ${ }^{19}$ Kedua pasien akan mengalami keterbatasan untuk melakukan pekerjaan dengan tangan kanannya sehingga menyulitkan pekerjaannya sebagai ibu rumah tangga dan melakukan kegiatan sehari-hari.
Tabel 2. Prognosis ${ }^{19}$

\begin{tabular}{ll}
\hline Parameter & Poin \\
\hline Skala Koma Glasgow & \\
$3-4$ & 2 \\
$5-12$ & 1 \\
$13-15$ & 0 \\
\hline $\begin{array}{l}\text { Volume perdarahan intraserebral }\left(\mathrm{cm}^{3}\right) \\
\quad \geq 30\end{array}$ \\
$\quad<30$ & 1 \\
\hline Perdarahan intraventrikular & 0 \\
$\quad$ Ya & \\
$\quad$ Tidak & 1 \\
\hline Perdarahan infratentorial & 0 \\
$\quad$ Ya & \\
Tidak & 1 \\
Usia & 0 \\
$\quad \geq 80$ tahun & \\
$<80$ tahun & 1 \\
\hline
\end{tabular}

\section{Simpulan}

Kondisi PIS yang terjadi saat kehamilan dan pascapersalinan menyebabkan morbiditas, mortalitas, serta menyulitkan proses diagnosis dan manajemen pasien. Penatalaksanaan stroke selama kehamilan memerlukan perawatan interdisipliner dari bedah saraf, neurologi, dan obstetri. Prinsip tata laksana pasien PIS serupa saat kondisi di luar kehamilan, namun membutuhkan perhatian khusus dalam pemilihan terapi.

\section{Konflik Kepentingan}

Laporan penelitian ini diajukan dalam sesi ilmiah presentasi poster di The Bali Neurology Update 5th yang diselenggarakan oleh Perhimpunan Dokter Spesialis Saraf Indonesia cabang Denpasar bekerja sama dengan Fakultas Kedokteran Universitas Udayana dan Rumah Sakit Umum Pusat Sanglah Denpasar tanggal 22-24 September 2017 di Denpasar, Bali 


\section{Daftar Rujukan}

1. Tate J dan Bushnell C. Pregnancy and stroke risk in women. Womens Health (Lond) 2011; 7(3): 363-374.

2. Kittner S, Stern BJ, Feeser BR, dkk.Pregnancy and the risk of stroke. N Eng J Med 1996; 335 (11): 768-774.

3. Laadioui M, Bouzoubaa W, Jayi S, dkk. Spontaneous hemorrhagic strokes during pregnancy: case report and review of the literature. Pan Afr Med J 2014; 19: 372.

4. Grear K dan Bushnell C. Stroke and pregnancy: clinical presentation, evaluation, treatment, and epidemiology. Clin Obstet Gynecol 2013; 56(2): 350-359.

5. Yoshida K, Takahashi JC, Takenobu Y, dkk. Strokes Associated With Pregnancy and Puerperium: A Nationwide Study by the Japan Stroke Society. Stroke 2017; 48(2): 276-282.

6. Macellari F, Paciaroni M, Agnelli G, dkk. Neuroimaging in intracerebral hemorrhage. Stroke 2014; 45(3): 903-908.

7. Domingues R, Rossi C, Cordonnier C. Diagnostic evaluation for nontraumatic intracerebral hemorrhage. Neurol Clin 2015; 33(2): 315-328.

8. Smith EE, Shobha N Dai D dkk. A risk score for in-hospital death in patients admitted with ischemic or hemorrhagic stroke. J Am Heart Assoc 2013; 2(1): 1-11.

9. Provenzale J dan Kranz P. Dural sinus thrombosis: sources of error in image interpretation. AJR Am J Roentgenol 2011; 196(1): 23-31.

10.Delgado-Almandoz J, Schaefer PW, Goldstein JN, dkk. Practical Scoring System for the Identification of Patients with Intracerebral
Hemorrhage at Highest Risk of Harboring an Underlying Vascular Etiology: The Secondary Intracerebral Hemorrhage Score. AJNR Am J Neuroradiol 2010; 31(9): 1653-1660.

11.Birenbaum D. Emergency neurological care of strokes and bleeds. J Emerg Trauma Shock 2010; 3(1): 52-61.

12. Chalouhi N Hoh B, Hasan D. Review of cerebral aneurysm formation, growth, and rupture. Stroke 2013; 44(12): 3613-3622.

13.Xianli L, Peng L, Youxiang L. The clinical characteristics and treatment of cerebral AVM in pregnancy. Neuroradiol J 2015; 28(3): 234 237.

14.Liu XJ, Wang S, Zhao YL, dkk. Risk of cerebral arteriovenous malformation rupture during pregnancy and puerperium. Neurology 2014; 82(20): 1798-1803.

15.Ajiboye N, Chalouhi N, Starke RM, dkk. Unruptured Cerebral Aneurysms: Evaluation and Management. ScientificWorldJournal 2015.

16. McCollough CH, Schueler BA, Atwell TD, dkk. Radiation exposure and pregnancy: when should we be concerned?. Radiographics 2007; 27(4): 909-917.

17.Dias $M$ dan Sekhar L. Intracranial hemorrhage from aneurysms and arteriovenous malformations during pregnancy and the puerperium. Neurosurgery 1990; 27(6): 855 865.

18. Kelompok Studi Stroke. 2011. Guideline Stroke. Jakarta: Perhimpunan Dokter Spesialis Saraf Indonesia (PERDOSSI).

19. Hemphill J, Bonovich DC, Besmertis L, dkk.The ICH score: a simple, reliable grading scale for intracerebral hemorrhage. Stroke 2001; 32(4): 891-897. 